\title{
SOILS RECOVERED FROM DISASTER DEBRIS - CHARACTERIZATION AND UTILIZATION -
}

\author{
Takeshi KATSUMI ${ }^{1}$, Masafumi OKAWARA ${ }^{2}$, Mitsuhiro KAWASHIMA ${ }^{3}$, \\ Kazuto ENDO ${ }^{4}$, Hirofumi SAKANAKURA ${ }^{4}$, Shinichi IWASHITA ${ }^{5}$, \\ Atsushi TAKAI ${ }^{6}$ and Toru INUI ${ }^{7}$ \\ ${ }^{1}$ Member of JSCE, Professor, Graduate School of Global Environmental Studies, Kyoto University \\ (Yoshida-honmachi, Sakyo-ku, Kyoto 606-8501, Japan) \\ E-mail: katsumi.takeshi.6v@kyoto-u.ac.jp \\ ${ }^{2}$ Member of JSCE, Associate Professor, Graduate School of Engineering, Iwate University \\ (4-3-5 Ueda, Morioka, Iwate 020-0105, Japan) \\ E-mail: okawara@iwate-u.ac.jp \\ ${ }^{3}$ Department of Environment and Residential Life, Iwate Prefectural Government \\ (10-1 Uchimaru, Morioka, Iwate 020-8570, Japan) \\ E-mail: M-Kawashima@pref.iwate.jp \\ ${ }^{4}$ Member of JSCE, Center for Material Cycles and Waste Management Research, National Institute \\ for Environmental Studies (16-2 Onogawa, Tsukuba, Ibaraki 305-8506, Japan) \\ E-mail: k-endo@nies.go.jp, sakanakura@nies.go.jp \\ ${ }^{5}$ Executive Officer, Oyo Corporation (7 Mitoshiro-cho, Kanda, Chiyoda-ku, Tokyo 101-8486, Japan) \\ E-mail: iwashita-shinichi@oyonet.oyo.co.jp \\ ${ }^{6}$ Member of JSCE, Assistant Professor, Graduate School of Global Environmental Studies, Kyoto University \\ (Yoshida-honmachi, Sakyo-ku, Kyoto 606-8501, Japan) \\ E-mail: takai.atsushi.2s@kyoto-u.ac.jp \\ ${ }^{7}$ Member of JSCE, Associate Professor, Graduate School of Global Environmental Studies, Kyoto University \\ (Yoshida-honmachi, Sakyo-ku, Kyoto 606-8501, Japan) \\ E-mail: inui.toru.3v@kyoto-u.ac.jp
}

\begin{abstract}
Utilization of soil fractions recovered from disaster debris as geomaterials was highly desirable after the 2011 East Japan earthquake and tsunami because the soil fraction accounted for a third of the approximately 30 million-ton disaster debris and tsunami deposits. Because the quality of recovered soils varied according to treatment systems at each site, as well as the characteristics of original soils, clarification of material properties of recovered soils is important for future catastrophic disaster. In this paper, generation and treatment of disaster debris are briefly summarized. A total of 404 data items, which were obtained in Iwate Prefecture, were analyzed to verify the properties of the recovered soils in relation to the treatment methods. A series of analyses indicated that the soil fractions recovered from disaster debris have quality equivalent to general geomaterials.
\end{abstract}

Key Words : disaster debris, reuse, embankment, characterization, disaster recovery

\section{INTRODUCTION}

Management of the wastes and debris generated at catastrophic natural disasters is one of the important considerations for disaster recovery. The 2011 earthquake off the Pacific coast of Tohoku has caused several significant problems regarding disaster waste management, and many of them have been solved due to the efforts provided by many governmental and private institutions and individuals. The basic concept of disaster waste management was to separate wastes based on the materials, to reuse the separated fractions, and to minimize the landfills. There were numerous challenges, experiences, and lessons learned through these disaster waste management initiatives, which have been summarized by the national government to utilize them for future disasters ${ }^{1)}$.

The disaster debris and tsunami deposits included a significant amount of soil fractions. Utilization of treated disaster debris, in particular recovered soils, in recovery works was strongly expected, because 
recovery works were considered to require a large amount of soil materials for reconstruction. However, the use of recovered soils in recovery works was temporarily stopped in the early stage (e.g., in 2011 and 2012). It was probably because knowledge and experiences were limited since such a large amount of soil-waste mixtures had never been subjected for consideration in Japan before, and because proper allocation of the materials had never been discussed. Numerous efforts were therefore made by many institutions to overcome such negative understanding and to promote utilizations. For example, national and local governments published technical guidelines on the use of such recovered materials. An academic society, The Japanese Geotechnical Society (JGS), conducted a series of round-robin experiments on the separated materials so as to contribute to establishing the technical guideline by the Iwate Prefecture. JGS also published "recommendations" and its original guideline on the use of recovered materials. This paper aims to summarize these efforts. First, the status of generation and treatment of disaster wastes is summarized. Second, the material properties of recovered soils are briefly analyzed. Third, technical efforts to promote the use of recovered soils in reconstruction works are summarized.

\section{GENERATION AND TREATMENT OF DISASTER DEBRIS}

\section{(1) Generation}

An earthquake of magnitude $9.03 \mathrm{Mw}$, referred to as the 2011 earthquake off the Pacific coast of Tohoku, occurred at 14:46 on March 11, 2011. It was one of the five most powerful earthquakes in the world since modern record-keeping started. The earthquake triggered a tsunami that reached heights of up to $40.5 \mathrm{~m}$ at maximum in Miyako City, Iwate Prefecture, and traveled up to $10 \mathrm{~km}$ inland in the
Sendai plane in Miyagi Prefecture.

Immediately after the 2011 earthquake off the Pacific coast of Tohoku and subsequent tsunami, the government estimated that approximately $20,000 \mathrm{Gg}$ (20,000,000 ton) of disaster debris and $10,000 \mathrm{Gg}$ of tsunami deposit had been generated through this disaster mostly in Iwate, Miyagi, and Fukushima Prefectures. Tsunami deposits are the soils transported by the tsunami and, similarly to other disaster debris, they also require proper treatment. The magnitude of disaster debris generation was comparable to previous catastrophic disasters such as the 2010 Haiti earthquake, 2008 Sichuan earthquake in China, etc., as summarized by Brown et al. ${ }^{2}$. It was geographically and economically unrealistic to construct new landfill sites with sufficient capacities to accept these wastes, since their amounts were several times larger than those of the annually generated municipal solid wastes in each local municipality. For example, disaster debris generation in Iwate Prefecture corresponded to 12-year municipal solid waste (MSW) generation in the whole prefecture. In a more severe case, in Rikuzentakata City, Iwate Prefecture, it corresponded to 280-year local MSW generation. Reuse of these materials was, therefore, required. The national government decided that proper treatment and utilization of debris and tsunami deposits should be completed by 2014 March $^{3), 4)}$. Treatment of the disaster wastes generated by this earthquake has been a big challenge, since such a large amount of mixed wastes had never been generated in Japan before. A significant fraction of these wastes corresponded to tsunami deposit soils. Fig. 1 shows the fractions of generated waste materials in Iwate, Miyagi, and Fukushima Prefectures ${ }^{5}$.

\section{(2) Overview of the treatment}

The national government decided to complete disaster waste treatment within three years through a national subsidy. While the detailed processes of
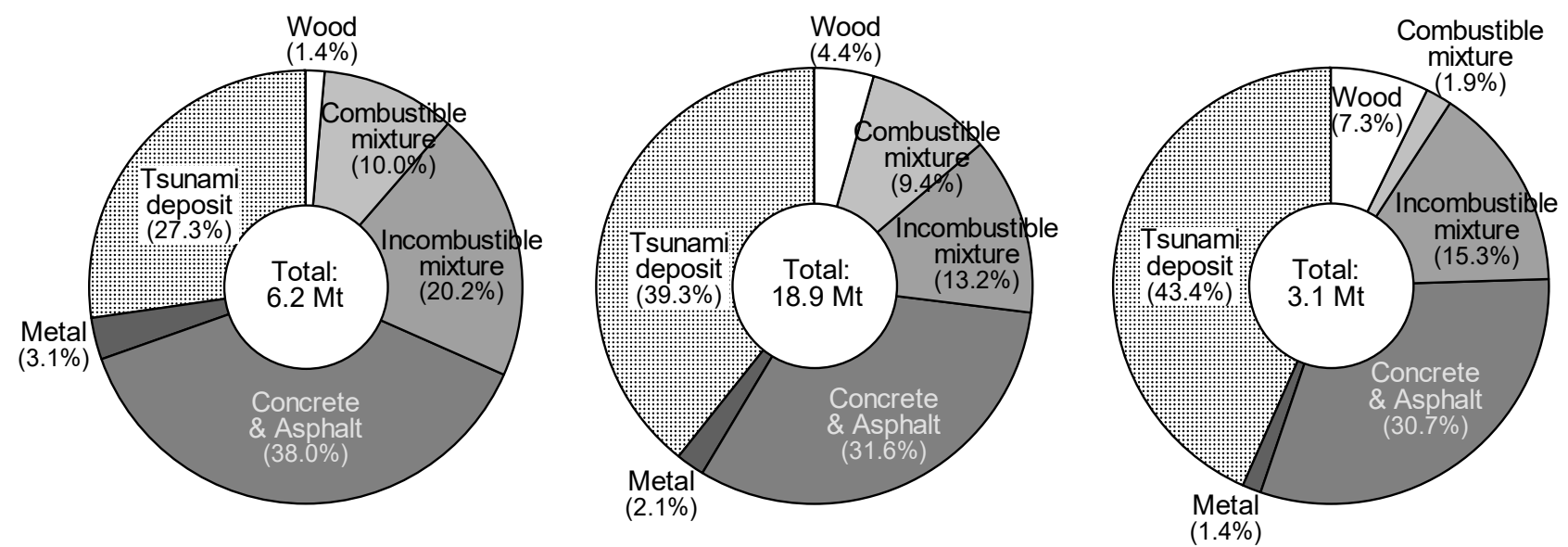

Fig.1 Composition of disaster debris in Iwate (left), Miyagi (center), and Fukushima (right) Prefectures as of 2014 March (data from MOE 2014) ${ }^{5), 6 \text {. }}$. 
disaster debris treatment vary by municipality, a common system can be illustrated in Fig. 2. First, the debris was cleared from the affected sites, collected, and transported to primary storage sites, which reached more than 300 sites at their peak. At the primary storage sites, wastes were stockpiled depending on the separation upon collection, such as waste mixtures dominant with burnable materials (e.g., collapsed wooden houses), concrete-dominant stockpiles, tatami mat dominant stockpiles, soil-dominant stockpiles, etc. Only rough separation, such as separation using operation vehicles and manual separation, was conducted. After the rough separation, an "advanced treatment" was conducted at the secondary storage and treatment sites, which were set at one or two sites per municipality (approximately 30 sites in Miyagi and Iwate Prefectures). This "advanced treatment" can also be called "mechanical treatment" because various mechanical equipment and/or machineries were installed. It can also be called "advanced separation" because most of the systems installed in each municipality resulted in the separation. "Separation" systems mostly consisted of several processes of "crushing" and "separating," as shown in Fig. 3. The basic idea of the separation system was to separate mixed wastes into fractions based on the substances, such as burnable materials, unburnable materials, metals, etc. As for the soil-dominant stockpiles which were mainly collections of tsunami deposits, only sieving (sepa- ration using sieve) was mostly conducted to separate soils from the wastes.

The "advanced treatment" system varied from site to site, depending on the different given conditions of the materials to be treated (amount of disaster debris generation, primary separation and storage, type of original soil, etc.), site environment (area limitation, air pollution risks, number of primary storage sites, etc.), and local resources (waste incinerators, cement plants, etc.). One example of these "advanced treatment" systems is illustrated in Fig. 4, in which three "separation" processes using sieving machines (vibrating screen, 35-mm-opening rotating screen,

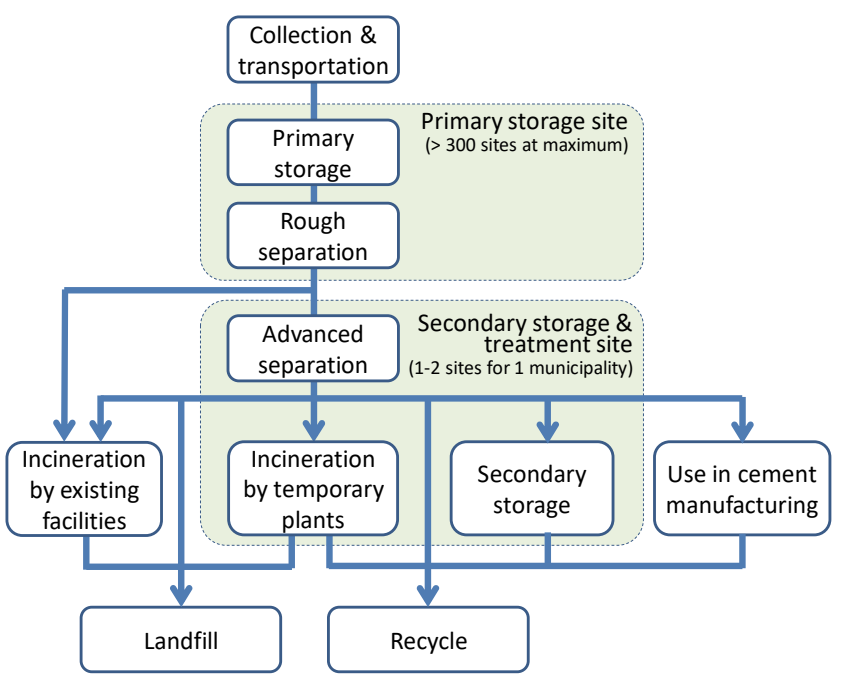

Fig.2 Basic flow of disaster waste management ${ }^{6)}$.

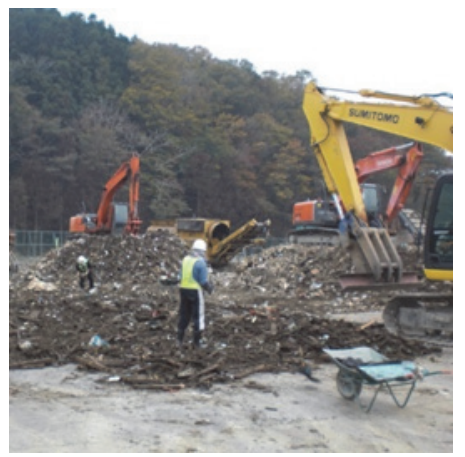

Manual separation using heavy machines

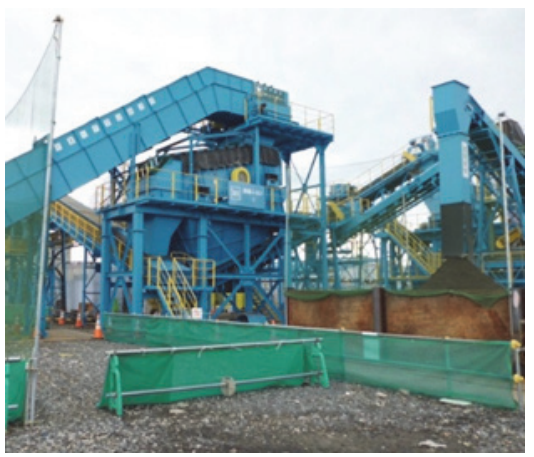

Vibration screen

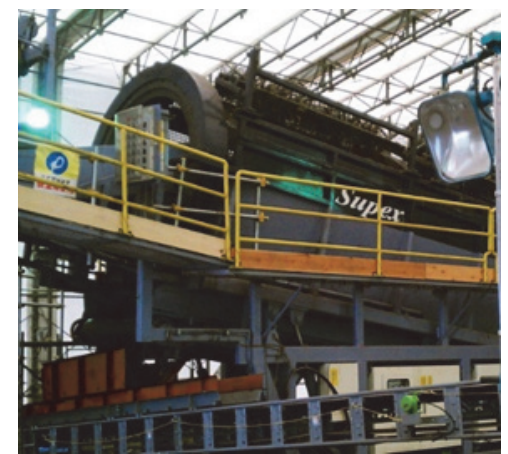

Rotation screen

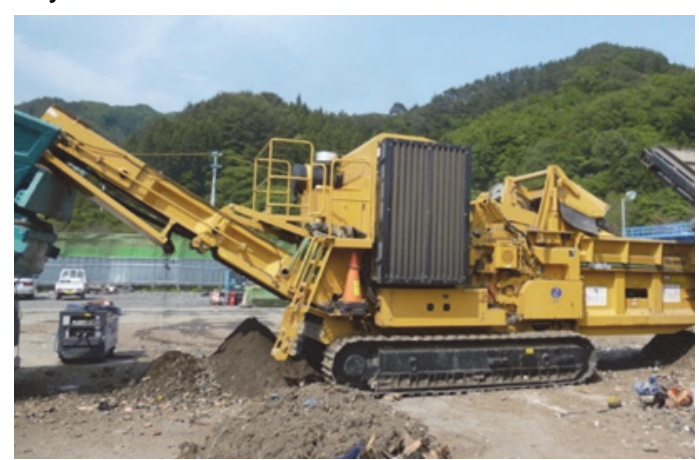

Crushing machine

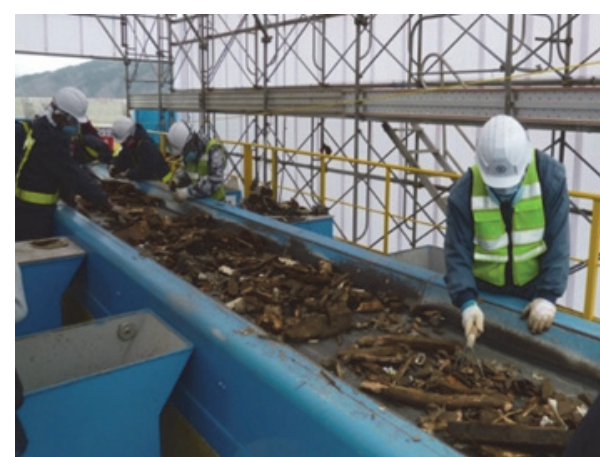

Manual separation by hand

Fig.3 Examples of separation and crushing processes ${ }^{6}$. 


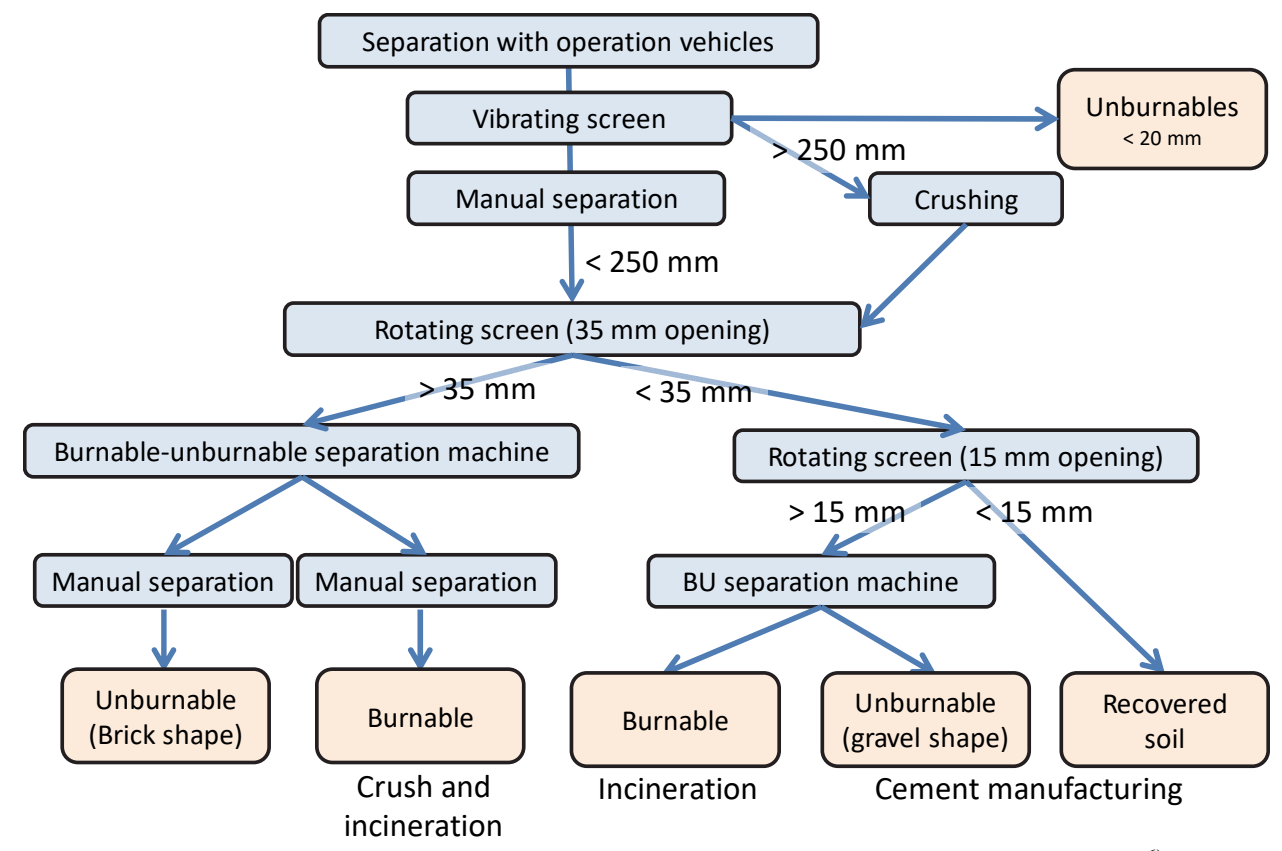

Fig.4 Example of disaster waste treatment system in Noda town, Iwate Prefecture ${ }^{6}$.

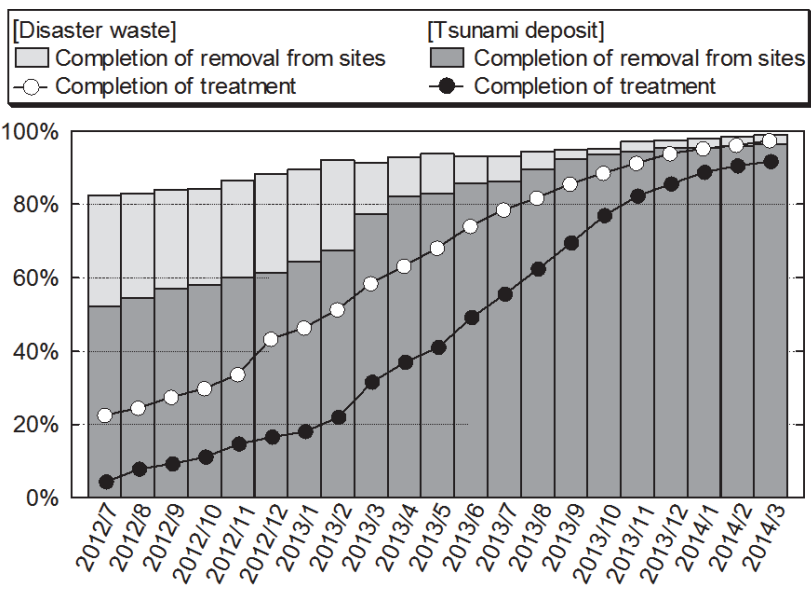

Fig.5 State of progress of disaster debris treatment (data from MOE 2014) $)^{5), 6)}$.

and 15-mm-opening rotating screen), one "crushing" process, and three "separation" processes using manual separation, and two "separation" processes using special machines to separate burnable fractions from waste mixtures.

The materials obtained from the advanced separation process were distributed for (1) incineration treatment in existing incineration plants, (2) incineration using temporary plants, (3) secondary storage, (4) utilization, (5) landfill, or (6) use for cement manufacturing, as shown in Fig. 2. Since the capacity of the existing incineration plants in the local areas was limited, temporary incineration plants were installed in the treatment sites of each municipality in Miyagi Prefecture. Discussion was made on the utilization, in geotechnical application, of incinerator ashes discharged from these temporary plants ${ }^{7)}$. In Iwate Prefecture, disaster wastes after advanced separation were used as raw materials or energy sources at the cement factories existing in the coastal area. One of these cement factories was damaged by tsunami, recovered in several months, and started to produce cement using disaster debris-treated materials in November 2011 after some cement production trials. As for the separated soils, or recovered soils, most of them were utilized in reconstruction works.

The state of the progress of disaster waste treatment is presented in Fig. 5. Here, tsunami deposit is differentiated from other wastes partly because, right after the earthquake, a decision on which governmental section would take responsibility for the treatment had not been yet decided. Note that the $\mathrm{x}$-axis starts from July 2012, while the disaster occurred March 2011. "Completion of treatment" corresponds to the "advanced separation" stage indicated in Fig. 2. This "advanced separation" was completed in three years (by March 2014) in most places except for some in Fukushima Prefecture due to the high concentration of nuclides caused by the Fukushima Daiichi Nuclear Power Station accident. State of the progress varied from municipality to municipality depending on several given conditions. Extreme efforts were required in some municipalities to complete disaster debris treatment by March 2014. The progress on the treatment of tsunami deposits was slower than that of disaster debris because it was likely that tsunami deposits were treated after the application of treated materials was decided, or because they were stored at the temporary storage sites before the utilization. 


\section{BASIC POLICIES FOR UTILIZATION OF RECOVERED SOILS}

At the affected areas, recovery works were conducted. In particular, countermeasures against ground subsidence and future anticipated tsunami were important considerations, because ground subsidence occurred due to the earthquake. For example, maximum lateral and vertical movements were recorded at $5.3 \mathrm{~m}$ and $-1.2 \mathrm{~m}$, respectively, at Oshika Peninsula in Miyagi Prefecture. Many other places along the Pacific coast at Iwate, Miyagi, and Fukushima Prefectures suffered more than $0.5 \mathrm{~m}$ ground subsidence ${ }^{8)}$. Embankment was therefore necessary for the recovery both for residential, commercial, and green areas. Utilization of the materials treated from the disaster wastes and tsunami deposits had strongly been expected. In particular, the geotechnical utilization of the soil fraction in disaster debris and tsunami deposits has become a big challenge for geotechnical engineers since temporal and spatial variations in the geotechnical properties of waste-mixed soils or recovered soils should be considered if a large amount of these soils are used for constructing embankments and levees against tsunami in reconstruction projects.

Utilization of treated disaster debris in recovery works has been an important consideration since the disaster. The Ministry of the Environment (2012) presented the requirements for utilization, namely (1) materials after necessary treatment, (2) materials free from non-toxic chemicals, (3) materials without environmental concerns, (4) utilization in public works, (5) materials satisfying the criteria required for structures, and (6) necessary tracing conducted ${ }^{9}$. To promote the utilization of treated disaster debris in recovery works, the Ministry of Land, Infrastructure, Transports and Tourism (MLIT) established two technical guidelines to construct (1) parks and green spaces as redundancy zones against tsunamis in which embankments must be constructed using disaster wastes, and (2) fill embankments at the areas where ground subsidence occurred significantly due to the earthquake ${ }^{10), 11)}$. It was proved that green areas had a positive effect on reducing the energy of tsunami and trapping the flowing obstacles such as cars, while some trees did not have sufficient root depth, which resulted in insufficient resistance against tsunami. Therefore, embankment construction for green areas has been considered advantageous to provide a sufficient distance from groundwater table to the ground surface. The Forestry Agency has also established a document for the use of treated materials in embankments of seaside forests ${ }^{12}$.

The material criteria proposed by the above guideline are shown in Table 1. There have been several discussions about these criteria. As for the salt content, to prevent the corrosion of underground steel materials, such as steel piles, and adverse impact on vegetation, a salt content lower than $1 \mathrm{mg} / \mathrm{g}$ is generally required. However, this technical guideline might consider the situation to construct embankments at the tsunami-affected areas, in which the salt concentration may already be high because they are located close to the ocean, although significant portion of the materials such as tsunami deposits may exceed this criteria of salt content as shown in Fig. 6 indicating the results of salt content of tsunami deposits ${ }^{13)}$. It was anticipated that the strict application of this criteria might limit the utilization of materials. Therefore, this technical guideline also covers the utilization of the materials having a salt content higher than $1 \mathrm{mg} / \mathrm{g}$.

Another concern of such materials is the potential of degradability, which may cause the generation of gas and leachate and ground settlement. In the field of waste management engineering, ignition loss has been normally used to evaluate the degradability. However, the ignition loss is not only reflected by degradable materials, but also by other components such as hydration products and organic components naturally contained in the original soil.

As summarized in Table 2, the definition of ignition loss varies by areas, although the Japan Society of Material Cycles and Waste Management suggested the ignition loss at $600 \pm 25^{\circ} \mathrm{C}$ of $5 \%$ as a criterion for utilization of tsunami deposit. Since this

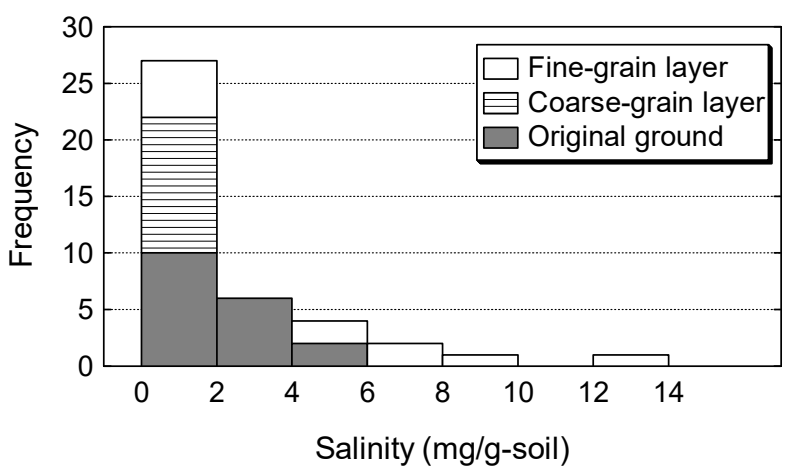

Fig. 6 Salinity of tsunami deposits collected at farmlands in Fukushima Prefecture ${ }^{13)}$.

Table 1 Criteria for the materials treated from disaster wastes used for embankment ${ }^{11)}$.

\begin{tabular}{|l|c|}
\hline \multicolumn{1}{|c|}{ Item } & Criteria \\
\hline Maximum grain size & $<300 \mathrm{~mm}$ \\
\hline Cone index & $>400 \mathrm{kN} / \mathrm{m}^{2}$ \\
\hline Salt content (in principle) & $<1 \mathrm{mg} / \mathrm{g}$ \\
\hline Electrical conductivity & $<200 \mathrm{mS} / \mathrm{m}$ \\
\hline $\mathrm{pH}$ & $6.0-9.0$ \\
\hline Swelling (at CBR soaking) & $>3 \%$ \\
\hline
\end{tabular}


Table 2 Definitions and purposes of ignition losses ${ }^{15}$.

\begin{tabular}{|l|l|}
\hline \multicolumn{1}{|c|}{ Area } & \multicolumn{1}{c|}{ Method and target } \\
\hline Geotechnics & $\begin{array}{l}\text { Ignition at } 750 \pm 50^{\circ} \mathrm{C} \text { for } 1 \text { hour } \\
\text { Volatile substances in soil such as or- } \\
\text { ganic matter, crystalline water, and } \\
\text { bound water, can be measured. }\end{array}$ \\
\hline Cement & $\begin{array}{l}\text { Ignition at } 975 \pm 25^{\circ} \mathrm{C}\left(700 \pm 25^{\circ} \mathrm{C} \text { for }\right. \\
\text { Portland cement }) \\
\text { Impurity content can be measured. }\end{array}$ \\
\hline $\begin{array}{l}\text { Waste } \\
\text { treatment }\end{array}$ & $\begin{array}{l}\text { Ignition at } 600 \pm 25^{\circ} \mathrm{C} \text { for } 3 \text { hours } \\
\text { Residue after incineration can be } \\
\text { measured. }\end{array}$ \\
\hline $\begin{array}{l}\text { Industrial } \\
\text { wastewater }\end{array}$ & $\begin{array}{l}\text { Ignition at } 600 \pm 25^{\circ} \mathrm{C} \text { for } 30 \text { minutes } \\
\text { Inorganic matter content in industrial } \\
\text { wastewater can be measured. }\end{array}$ \\
\hline
\end{tabular}

ignition loss at $600 \pm 25^{\circ} \mathrm{C}$ is for quantifying an amount of residue after incineration of waste, it is not reasonable to judge quality of recovered soil and tsunami deposit as geomaterial by this value. Takai et al. and Katsumi et al. proposed to apply $330^{\circ} \mathrm{C}$ because combustion point of organic matters was observed at around $330^{\circ} \mathrm{C}^{14), 15}$. It is therefore required to establish comprehensive criteria to evaluate the intactness of materials.

\section{CHARACTERIZATION OF RECOV- ERED SOILS}

\section{(1) Classification of recovered soils}

Several preliminary studies (e.g., Morita et al. ${ }^{16}$ ) found that soil-waste mixture and recovered soils vary on their properties. Evaluation of site-specific properties of such recovered soils was necessary for the following reasons:

- Original soils vary site by site. Soil-waste mixtures with clayey soils may be more difficult to be separated than those with sandy soils, and more wooden fractions may remain in recovered soils.

- Disaster debris also varies site by site. Not only original materials and their fractions of debris are different, but also the way to be transported and stored in stockpiles may also be different, which may affect the properties of the separated materials.

- Treatment methods vary also site by site, depending on the technical proposals by the companies engaged in the disaster waste management in each municipality. This variation may also affect the properties of the separated materials, in cluding recovered soils.

The above aspects can be summarized in Fig. 7 . The Japanese Geotechnical Society (JGS) Geoenvironmental Technical Committee on the 2011 East Japan Earthquake and Tsunami conducted a series of

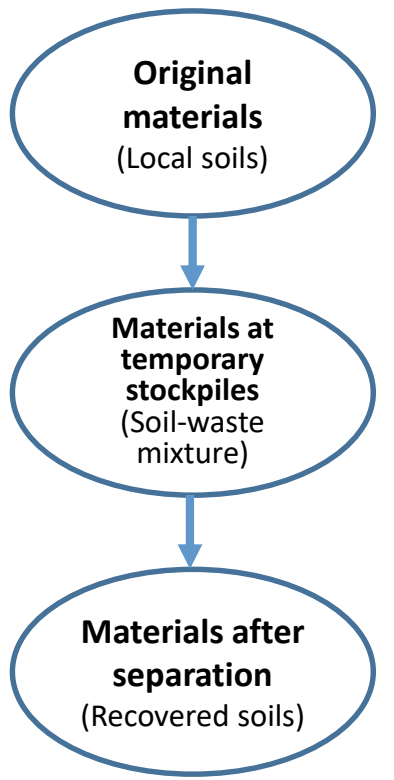

Fig. 7 Relations between original materials and materials at temporary stockpiles after separation ${ }^{6}$.

tests on the recovered materials obtained from several different cities and towns in Iwate Prefecture in late 2012 to early 2013. This voluntary-based work was done with more than 18 institutions, in order to obtain results in a timely manner to be reflected in Iwate Prefecture's Guideline for Utilization of Treated Wastes for the Recovery Works (Revised Version $)^{17)}$ and to contribute to the recovery works. The conducted experiments included basic properties (waste composition), physical properties (particle density, grain size distribution, liquid and plastic limits), chemical properties (ignition loss, $\mathrm{pH}$, electrical conductivity, chloride concentration (salinity), total organic carbon, and potential of sulphide formation), and geotechnical properties (compaction, cone index, CBR, and soaking). The results are presented in Okawara et al. ${ }^{18)}$.

In "Guideline for Utilization of Treated Wastes for the Recovery Works" published by Iwate Prefecture, "recovered soils" are categorized into three classes, namely, "Recovered Soil Class A," "Recovered Soil Class B," and "Separated Fine Fractions (Recovered Soil Class C)," depending on their origin and nature (Table 3) ${ }^{17)}$. "Recovered Soil Class A" refers to the soils separated from the soil-dominant stockpiles, mostly tsunami deposits, while "Class B" and "Class $\mathrm{C}$ " are the finer fractions obtained from wastedominant stockpiles, after rough and secondary separations, respectively. This categorization considered the strategic utilization of the recovered soil materials.

\section{(2) Basic properties of recovered soils}

In Iwate Prefecture, the recovered soils were subjected to the tests on material properties, based on 
"Guideline for Utilization of Treated Wastes for the Recovery Works." These practical data collected from a total of seven treatment sites-Kuji, Miyako, Yamada, Otsuchi, Kamaishi, Ofunato, and Rikuzentakata districts, from north to south-were analyzed and summarized by Takai et al. and Katsumi et al. ${ }^{19), 20)}$. Each site is located as shown in Fig. 8. While tsunami deposits and disaster debris were generally treated with processes consisting of crushing and separating as indicated in Chapter 2, some distinctive treatments were additionally conducted in Kamaishi, Ofunato, and Rikuzentakata districts for further improvement. Table 4 summarizes the distinctive points of treatment at each

Table 3 Classification of recovered soils designated by Iwate Prefecture ${ }^{17)}$.

\begin{tabular}{|l|l|}
\hline \multicolumn{1}{|c|}{ Classes } & \multicolumn{1}{c|}{ Contents } \\
\hline $\begin{array}{l}\text { Recovered } \\
\text { Soil Class A }\end{array}$ & $\begin{array}{l}\text { Soils separated from soil-dominant } \\
\text { stockpiles }\end{array}$ \\
\hline $\begin{array}{l}\text { Recovered } \\
\text { Soil Class B }\end{array}$ & $\begin{array}{l}\text { Soils separated from waste-mixed } \\
\text { stockpiles, and satisfying the criteria } \\
\text { for utilization }\end{array}$ \\
\hline $\begin{array}{l}\text { Separated fine } \\
\text { fractions } \\
\text { (Recovered } \\
\text { Soil Class C) }\end{array}$ & $\begin{array}{l}\text { Fine fractions obtained through the } \\
\text { treatment process of disaster waste }\end{array}$ \\
\hline
\end{tabular}

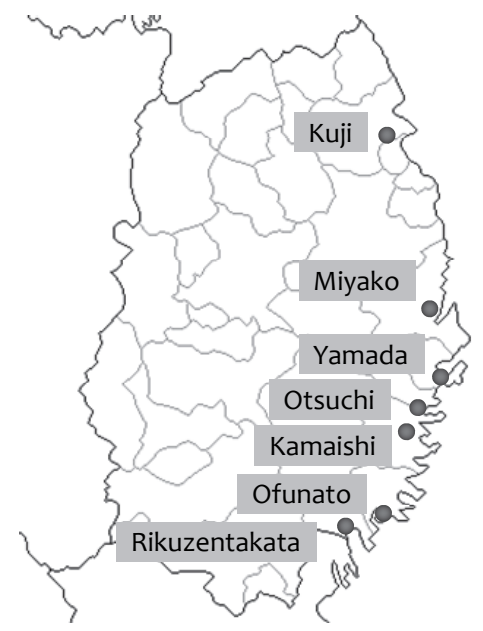

Fig. 8 Location of treatment sites in Iwate Prefecture ${ }^{21)}$. site. In Kamaishi and Ofunato districts, steel slag and crushed concrete, which were industrial by-products, were mixed with generated recovered materials, respectively, in anticipation of strength increase and further separation of soil fraction from debris. In Ofunato and Rikuzentakata, water separation method was used on some tsunami deposits and disaster debris to lower salinity. In Rikuzentakata, the treatment system was designed to utilize the recovered soils in agricultural applications. The total number of materials analyzed in Takai et al. ${ }^{19)}$ was 404 , which can be categorized into five types indicated in Table 5. "Others" includes soils through wet processing in Ofunato and Rikuzentakata, sand and clay fractions through wet cyclones in Ofunato, and tsunami deposit on farmlands in Rikuzentakata.

Particle densities are summarized in Fig. 9. Regardless of types of recovered material, the mode value of particle density was around $2.7 \mathrm{~g} / \mathrm{cm}^{3}$ at Kuji, Miyako, Yamada, and Otsuchi where no additional processes were applied. The particle density of Recovered Soil Class B was relatively smaller than

Table 4 Summary of distinctive treatment at each site ${ }^{21)}$.

\begin{tabular}{|c|c|}
\hline Site & Distinctive points about treatment \\
\hline Kamaishi & $\begin{array}{l}\text { - Steel slag was mixed with Recovered Soil } \\
\text { Class A and Class B. }\end{array}$ \\
\hline Ofunato & $\begin{array}{l}\text { - Crushed concrete was mixed with } \\
\text { Recovered Soil Class B. } \\
\text { - After some of the deposits and debris were } \\
\text { treated by wet processing for desalting, } \\
\text { sand and clay fractions were separately } \\
\text { obtained by wet cyclones using difference } \\
\text { in specific gravity. Then, lime was mixed } \\
\text { for dehydration. }\end{array}$ \\
\hline $\begin{array}{l}\text { Rikuzen- } \\
\text { takata }\end{array}$ & $\begin{array}{l}\text { - Recovered materials were mainly utilized } \\
\text { in farmland. } \\
\text { - Tsunami deposits on farmland were } \\
\text { separately removed from affected areas. } \\
\text { - After some of the deposits and debris were } \\
\text { treated by wet processing, particle size of } \\
\text { generated materials were adjusted by } \\
\text { mixing with clean soil. }\end{array}$ \\
\hline
\end{tabular}

Table 5 Types and number of samples analyzed in this study ${ }^{20), 21) .}$

\begin{tabular}{|l|r|r|r|r|r|r|}
\hline Site name & $\begin{array}{c}\text { Recovered } \\
\text { Soil Class A }\end{array}$ & $\begin{array}{c}\text { Recovered } \\
\text { Soil Class B }\end{array}$ & $\begin{array}{c}\text { Separated Fine } \\
\text { Fractions }\end{array}$ & Residue & Others & Subtotal \\
\hline Kuji & 20 & 5 & - & - & - & 25 \\
\hline Miyako & 69 & 13 & 2 & 1 & - & 85 \\
\hline Yamada & 15 & 8 & 3 & 1 & - & 27 \\
\hline Otsuchi & 52 & 16 & - & 1 & - & 69 \\
\hline Kamaishi & 16 & 34 & - & - & - & 50 \\
\hline Ofunato & 2 & 35 & - & 8 & 15 & 60 \\
\hline Rikuzentakata & 77 & - & - & - & 11 & 88 \\
\hline \hline Subtotal & 251 & 111 & 5 & 11 & 26 & 404 \\
\hline
\end{tabular}




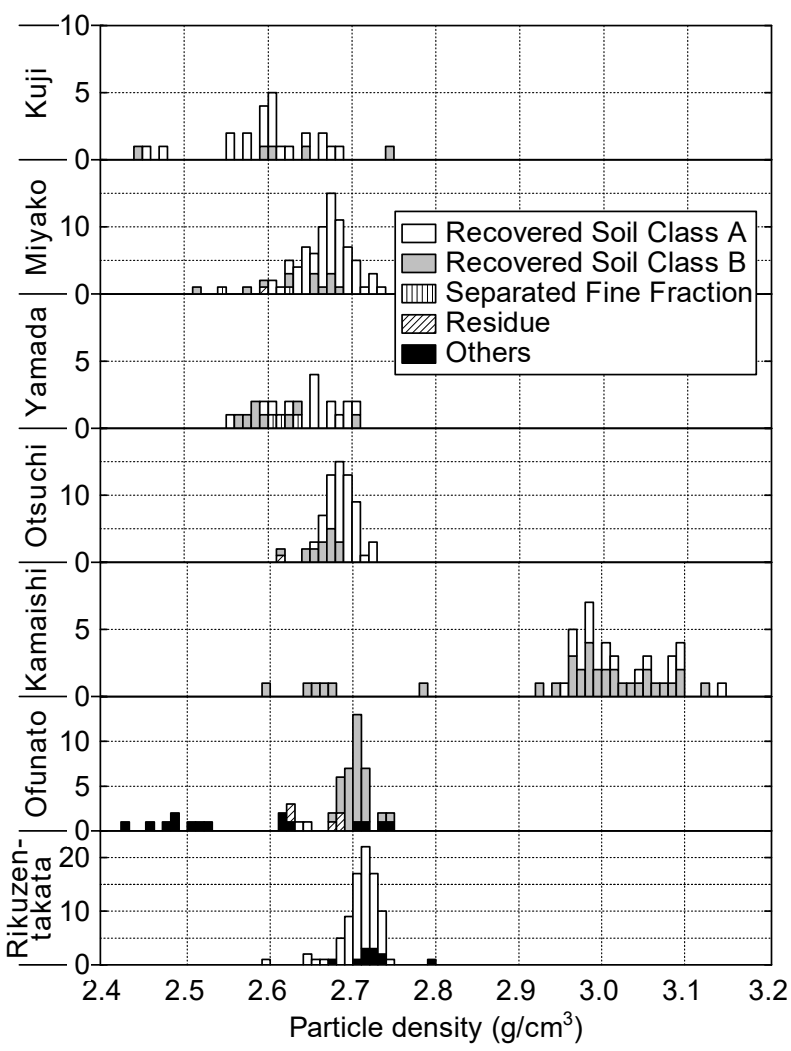

Fig. 9 Frequency distribution of particle density ${ }^{19), 20)}$.

that of Recovered Soil Class A possibly due to larger amount of wood fraction. The fact that the distribution peak shifted to right from north to south indicates that original seabed sediments had locally different characteristics. In Kamaishi, while the particle density of the recovered soils without additional treatment ranged within $2.8 \mathrm{~g} / \mathrm{cm}^{3}$ similar to those of the four districts, the recovered soils improved by steel slag showed particle density over $2.90 \mathrm{~g} / \mathrm{cm}^{3}$. This result is adequate considering that the steel slag with particle density of $3.3-3.6 \mathrm{~g} / \mathrm{cm}^{3}$ was added to recovered soils in a mass ratio of approximately $30 \%$. In Ofunato where sand and clay fractions were separately obtained through wet cyclones, sand fraction was larger than clay fraction, which ranged from 2.4 to $2.6 \mathrm{~g} / \mathrm{cm}^{3}$.

Clay content was evaluated as shown in Fig. 10 to verify relationships with chemical properties. In the four districts where no additional processes were applied, recovered materials basically contained clay fraction of less than $20 \%$, regardless of types of recovered material. In Kamaishi, fine particles seem to be removed or scattered during treatment because clay content of all materials was less than $10 \%$; however, in fact, this result is attributed to large particle density mentioned above. Since steel slag is mainly composed of sandy fraction having heavy particles, mass content of fine fractions became relatively smaller compared to those in other districts. Correspondingly in Ofunato, as coarse crushed con-

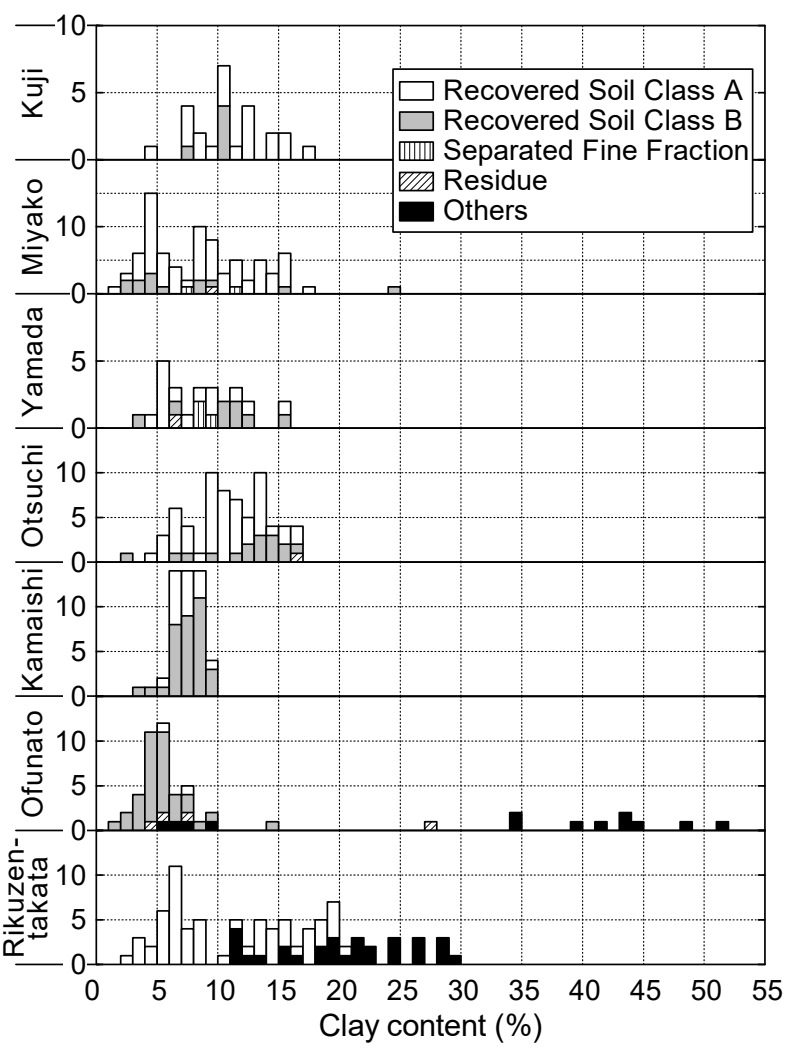

Fig. 10 Frequency distribution of clay content ${ }^{19), 20)}$.

crete was added for improvement, clay content was relatively low below $10 \%$. Clay materials that were separately obtained through wet cyclones in this district surely showed high clay content over $25 \%$ up to $52 \%$. In Rikuzentakata, clay content was relatively high because sand and clay fractions were intentionally mixed for agricultural purposes.

Soil classification based on JGS 0051-2009 is presented in Fig. 11. Original soils are considered to vary site by site. Takai et al. presented the properties of 1400 tsunami deposit specimens obtained from farmland affected by tsunami, and found that most of samples show poorly graded particle size distribution curves $^{13)}$. In contrast, Fig. 7 showed that most recovered soils from any district are categorized into SF (sandy soil with fine fractions), which inplies that grain sizes are widely distributed. It is because several different types of soils have been mixed together at the primary and secondary storage sites. At Rikuzentakata, fine fractions are relatively high, but still lower than $50 \%$, and consequently are also categorized as SF. Some of the specimens in Ofunato are categorized into GS (sandy gravel) or GF (gravel with fine fractions) because large-size concrete debris were mixed with the soils.

Frequency distributions of ignition loss are shown in Fig. 12. Here, ignition loss was tested according to JIS A 1226, which refers to the mass loss in a sample heated to $750^{\circ} \mathrm{C}$. In the four districts where no additional treatment was done, the ignition loss of Re- 


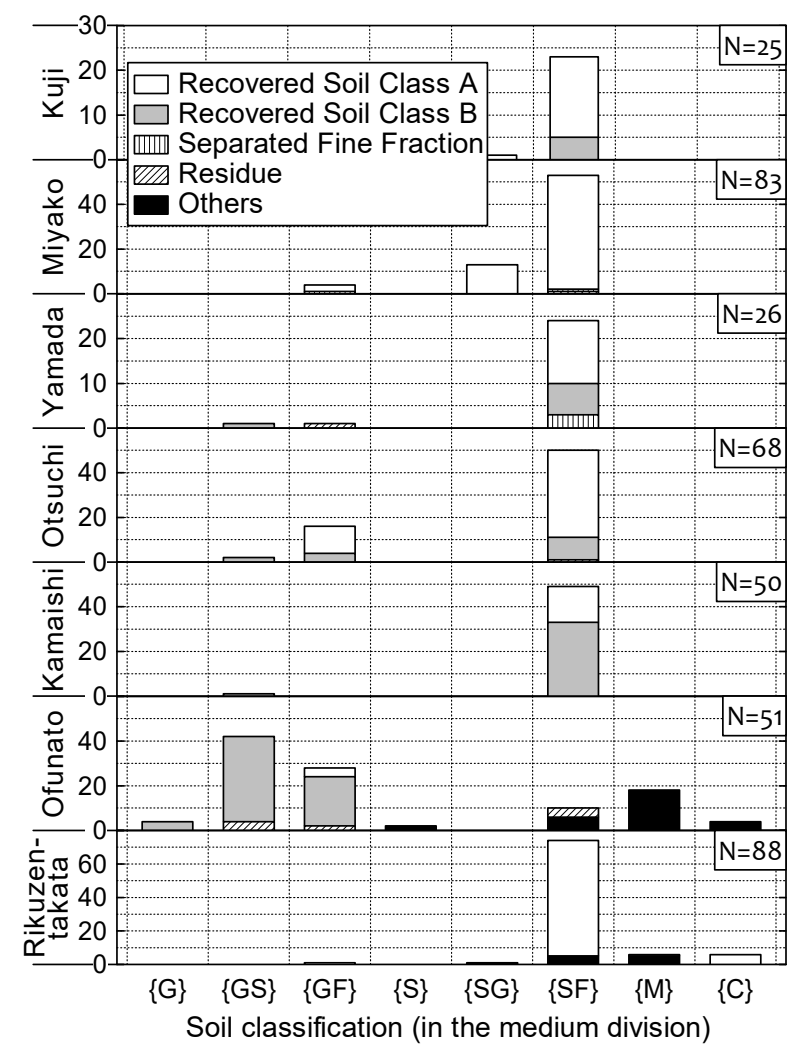

Fig. 11 Frequency distribution of soil classification ${ }^{19), 20)}$.

covered Soil Class B was relatively higher than that of Recovered Soil Class A due to larger amount of wood fraction included, but most of the materials showed values lower than $10 \%$ regardless of types. In Kamaishi where steel slag was used, the ignition loss was apparently small compared to those in other districts due to the large particle density of samples because the mass of incombustible matters includes the mass of steel slag. In Ofunato, the values were widely varied. Many materials showed the ignition loss higher than $10 \%$ due to cement hydrates by crushed concrete as well as organic matters. The ignition loss values of clay fraction separately obtained through wet cyclones were larger than $15 \%$, since hydrated water generated by the addition of lime for water content regulation greatly affected the values. These observations demonstrate that additive agents significantly affect the ignition loss of recovered materials. Although ignition loss is often referred as an index of organic matter content, which means purity of recovered materials in this case, a distinctive test method, e.g., heating at $330^{\circ} \mathrm{C}^{14)}$ as mentioned in the previous chapter, has to be established for adequate measurement of organic matter that remained in recovered materials.

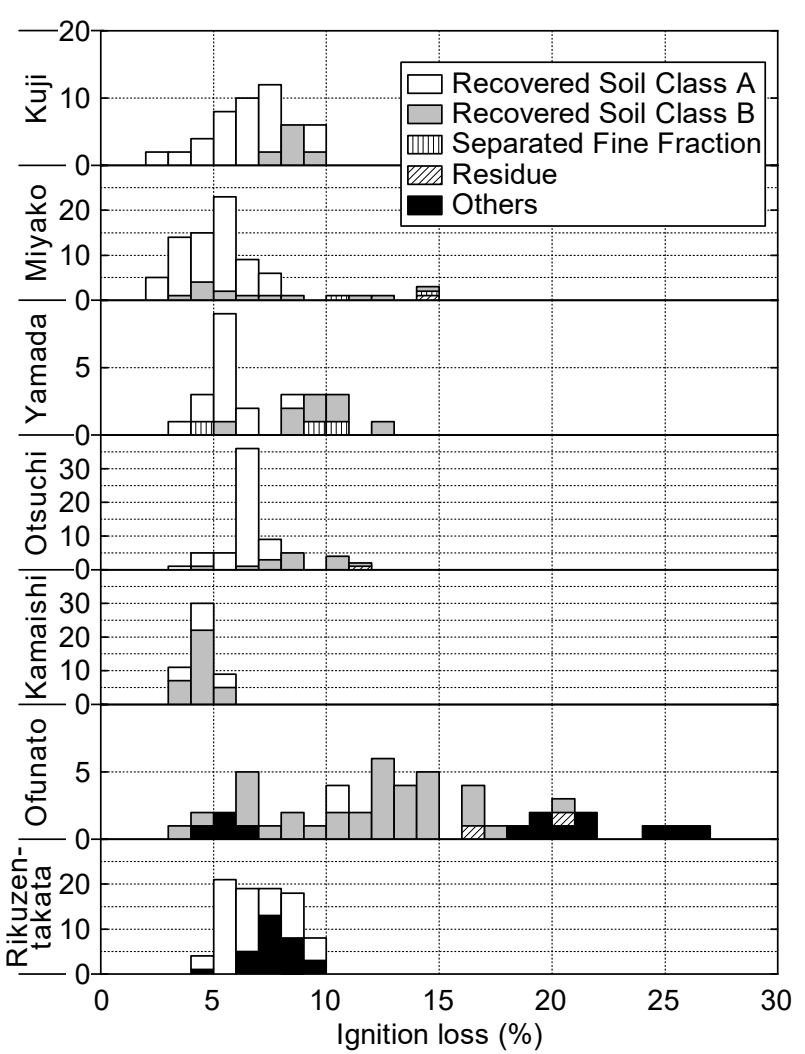

Fig. 12 Frequency distribution of ignition loss ${ }^{19), 20)}$.

\section{UTILIZATION OF RECOVERED SOILS IN RECOVERY WORKS}

Almost two years have passed since the disaster (2013 spring), when various institutions, particularly in Iwate, Miyagi, and Fukushima Prefectures, started to eagerly discuss the balance of supply and demand of soils. Large amount of soils were required not only for traditional infrastructure works for the recovery, but also for constructing larger sea dykes against future tsunami, as well as for elevating lands as countermeasures against land subsidence triggered by the earthquake. In early 2013, the local governments estimated the demand for soils $\left(58,000,000 \mathrm{~m}^{3}\right.$ in Iwate, $53,000,000 \mathrm{~m}^{3}$ in Miyagi, and $15,000,000$ $\mathrm{m}^{3}$ in Fukushima Prefectures) ${ }^{21)}$. Even though recovered soils obtained from disaster debris still existed, new soils were tried to be used in some recovery projects.

There was hesitation to promote the utilization of the soils recovered from the disaster debris, in particular from the waste-dominant stockpiles. Construction sectors of the local governments were rather conservative against the utilization of the soils obtained from the disaster wastes, because long-term properties were not well known. Since the government sectors assigned to manage the construction works were different from the sectors responsible for disaster waste management, utilization would not occur voluntarily, even if a manual or guidelines 

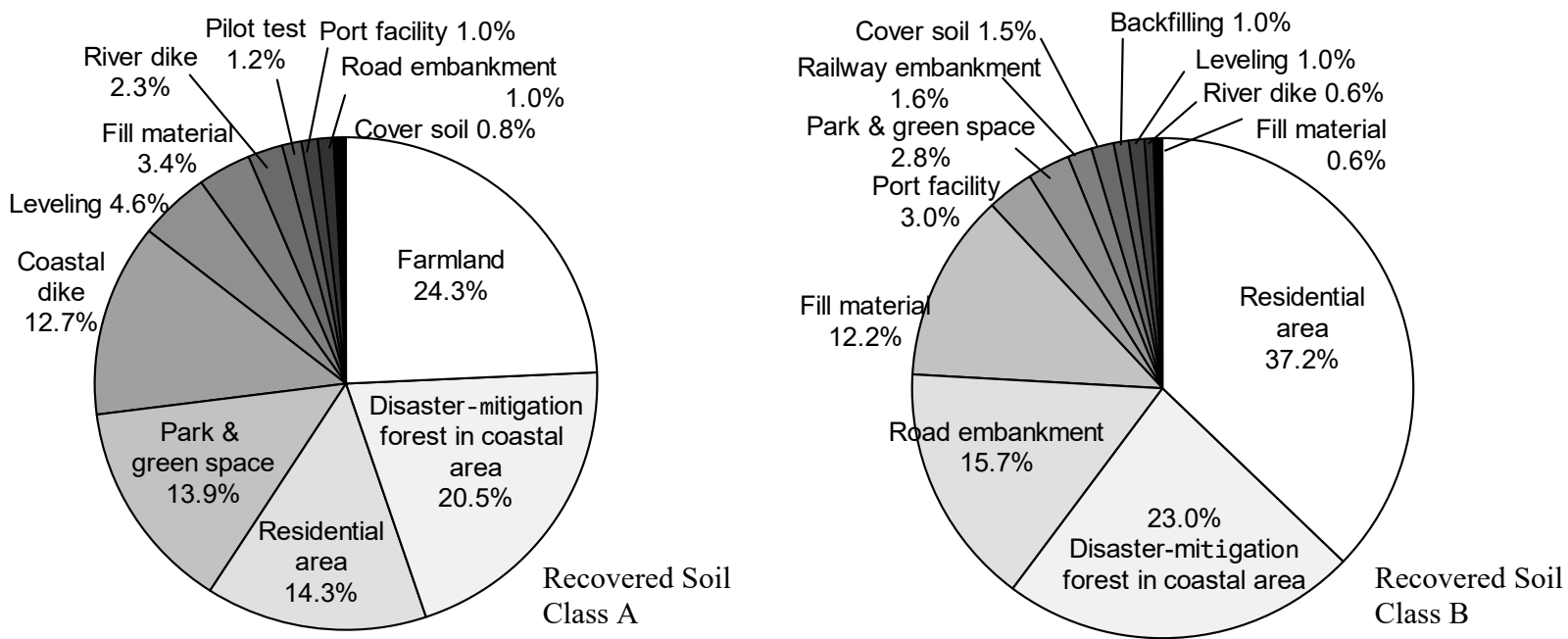

Fig. 13 Applications of recovered soils in Iwate Prefecture ${ }^{19)}$

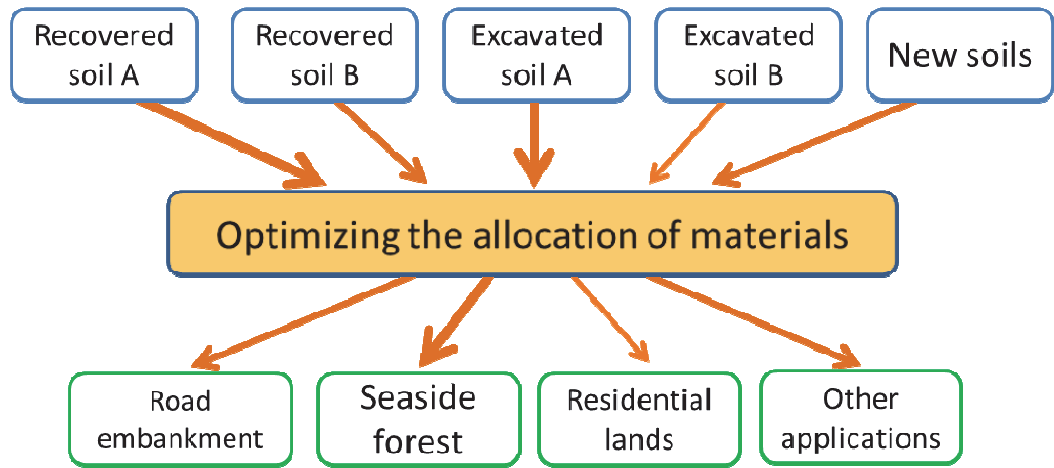

Fig. 14 Concept of integrated management of the soils for the disaster recovery discussed by JGS Technical Committee on Recovered Geo-materials ${ }^{21)}$.

were established. The creation of incentives to use these soils was also important.

In Iwate Prefecture, the use of recovered soils was earlier promoted. The classification of recovered soils was considered to have served in promoting the utilization. As a result, most of the recovered soils were transported to the site to be used by the time of completion of disaster waste management (2014 March). Fig. 13 shows the applications of Recovered Soil Class A and B. Farmlands, seaside forests, park and green spaces accepted approximately $60 \%$ of Class A soils. These applications do not apply sufficient overburden pressures or loads on the soils. Major applications for Class B soils are residential area, road embankement, fill materials, etc. Details of these applications are mostly sports ground, temporary road embankment for reconstruction works, and other similar applications, where the permanent loads are not anticipated. Traditional road embankemnts and fill materials accepted the recovered soils in Ofunato, because addition of crushed concrete debris contributed to the improvement in grain size distribution and the increase in strength.

The recovery and reconstruction works have been done by the environmental, construction, and for- estry sections of national, prefectural, and municipal governments, as well as by the private sector, including railway companies. There are not only recovered soils but also excavated soils, generated in large quantities to cut mountains to create new residential space. In some places, the new soil materials have been used due to the scarcity of natural materials. Awareness of the necessity of integrated management of the soil materials beyond these sections started in the related institutions.

The Japanese Geotechnical Society (JGS) established the Technical Committee on Recovered Geo-Materials (chaired by the first author) in 2013 with support from the National Institute for Environmental Studies and the Mud Recycling Association, to present a recommendation entitled "Use of Recovered Geo-Materials for the Disaster Recovery," to tie up with different institutions and sections for promoting the effective use of soils, either recovered, excavated, or new (Fig. 14). This recommendation consists of (1) backgrounds, (2) basic concepts, and (3) necessary actions ${ }^{21)}$. The original version is freely available from the web page of JGS. Besides, Katsumi et al. ${ }^{6}$ and Katsumi ${ }^{22)}$ provide the English-translated version. 
This technical committee published a 96-page guideline entitled "Guideline of Utilization of Recovered Materials from Disaster Wastes," based on the substantial discussions with the related institutions including Iwate, Miyagi, and Fukushima Prefectural Governments, Ministry of Agriculture, Forestry and Fisheries (MAFF), Ministry of Land, Infrastructure, Transport and Tourism (MLIT), and Ministry of the Environment (MOE) $)^{23)}$. This guideline has been referred in many occasions not only for disaster recovery but also for the utilization of traditional excavated soils with natural contamination and management of soils contaminated with nuclides. For example, it has been cited in the documents prepared by the Ministry of the Environment regarding waste management in anticipated future catastrophic earthquake ${ }^{1)}$. The experiences obtained and lessons learned through this recovery process are strongly expected to be utilized for future disaster recovery.

ACKNOWLEDGMENTS: Contributions and discussions provided by the members of the JGS Geoenvironmental Technical Committee on the 2011 East Japan Earthquake and Tsunami and JGS Technical Committee on Recovered Geo-Materials, both chaired by Katsumi, the first author of this paper, are greatly appreciated. Many individuals from Iwate, Miyagi, and Fukushima Prefectural Governments, Japan Ministry of Land, Infrastructure, Transport and Tourism (MLIT), Ministry of Environment (MOE), Forestry Agency, Reconstruction Agency, National Institute for Environmental Studies (NIES), Mud Recycling Association, and other institutions provided valuable information and discussions. Special appreciation is extended to the members of the Department of Environment and Residential Life, Iwate Prefectural Government for their considerable support and contributions. This work was supported by the Environment Research and Technology Development Funds (3K133003 and 3K163011) and JSPS KAKENHI Grants-in-Aid for Scientific Research (15H02264). Most parts of this paper are based on the authors' previous publications in the reference list.

\section{REFERENCES}

1) Ministry of the Environment: Summary Report on the Technical Aspects on Disaster Waste Treatment based on the Experiences through 2011 East Japan Earthquake, 2016 (in Japanese).

2) Brown, C., Milke, M. and Seville, E.: Disaster waste management: A review article, Waste Management, Vol. 31, pp. 1085-1098, 2011.

3) Ministry of the Environment: Master Plan for the Treatment of Disaster Waste Caused by the 2011 Great East Japan Earthquake, http://www.env.go.jp/jishin/attach/haiki _masterplan.pdf, 2011 (accessed on January 19, 2017, in Japanese).
4) Ministry of the Environment: Guideline on the Treatment of Tsunami Deposit, http://www.env.go.jp/jishin/attach/sisin 110713.pdf, 2011 (accessed on January 19, 2017, in Japanese).

5) Ministry of the Environment: Treatment of disaster debris from 2011 East Japan earthquake, http://kouikishori.env.go. jp/table/pdf/shori140425.pdf, 2014 (in Japanese).

6) Katsumi, T., Endo, K., Imanishi, H., Inui, T., Kazama, M., Nakashima, M., Okawara, M., Otsuka, Y., Sakamoto, H., Sakanakura, H., Suzuki, H., Takai, A. and Yasutaka, T.: Environmental geotechnics for the recovery from 2011 East Japan earthquake and tsunami, Proceedings of the Seventh International Congress on Environmental Geotechnics, A. Bouazza, S. T. S. Yuen and B. Brown (eds.), Engineers Australia (EA), pp. 170-189, 2014.

7) Sakanakura, H., Ozawa, K., Miura, T., Inui, T., Sakamoto, H., Sato, T., Nakano, M. and Yoshino, H.: Classification of discarded plasterboards based on trace elements concentration and leaching characteristics, Proceedings of 10th JGS Symposium on Environmental Geotechnics, JGS, pp. 419-426, 2013 (in Japanese).

8) Geospatial Information Authority of Japan: Land subsidence caused by 2011 Tōhoku earthquake and tsunami, http://www.gsi.go.jp/sokuchikijun/sokuchikijun40003.html, 2011 (accessed on January 19, 2017, in Japanese).

9) Ministry of the Environment: Notification on use of the materials recovered from disaster debris in public works for the recovery from 2011 East Japan earthquake, 2012 (in Japanese).

10) Ministry of Land, Infrastructure, and Transport: Technical Guideline on the Development of Parks and Green Spaces in the Reconstruction from the off the Pacific coast of Tohoku Earthquake Disaster, http://www.mlit.go.jp/ common/000205823.pdf, 2012 (accessed on January 19, 2017, in Japanese).

11) Ministry of Land, Infrastructure, and Transport: Basic Concepts on the Utilization of Recycled Materials in Constructing Fill Embankment to Accelerate the Revitalization from the Earthquake Disaster, http://www.mlit.go.jp/ common/000208618.pdf, 2012 (accessed on January 19, 2017, in Japanese).

12) Forestry Agency: Use of the materials recovered from disaster debris for creating seaside forests, 2012 (in Japanese).

13) Takai, A., Yasutaka, T., Endo, K. and Katsumi, T.: Distribution and physicochemical properties of tsunami deposits generated by the 2011 Great East Japan earthquake, Japanese Geotechnical Journal, Vol. 8, No. 3, pp. 391-402, 2013 (in Japanese).

14) Takai, A., Uddin, M. N., Inui, T. and Katsumi, T.: Mechanical properties of geomaterial recovered from disaster debris after the 2011 earthquake, Proceedings of the Seventh International Congress on Environmental Geotechnics, A. Bouazza, S. T. S. Yuen and B. Brown (eds.), Engineers Australia (EA), pp. 1602-1609, 2014.

15) Katsumi, T., Takai, A., Inui, T., Okawara, M., Endo, K. and Sakanakura, H.: Soils recovered from disaster debris, Proceedings of the Fifteenth Asian Regional Conference on Soil Mechanics and Geotechnical Engineering, Japanese Geotechnical Society Special Publication, Vol. 2, No. 54, pp. 1888-1892, 2015.

16) Morita, K., Katsumi, T., Takai, A. and Inui, T.: Characterization of waste mixed tsunami sediments generated by the 2011 East Japan earthquake and tsunami, Geo-Environmental Engineering 2012 - Proceedings of the 11th Japan-Korea-France-Canada Joint Seminar on Geoenvironmental Engineering, Caen University, pp. 33-42, 2012. 
17) Iwate Prefecture: Guideline for Utilization of Treated Wastes for the Recovery Works (Revised version), https://www.pref.iwate.jp/dbps_data/_material_/files/000/ 000/003/225/manual.pdf, 2013 (accessed on January 19, 2017, in Japanese)

18) Okawara, M., Otsuka, Y., Sakamoto, H., Takai, A., Imanishi, H., Endo, K., Omine, K., Kazama, M., Katoh, M., Kotake, N., Shuku, T., Suzuki, H., Nakagawa, M., Nakano, M., Nishimura, S., Fujikawa, T., Matsuyama, Y., Yamanaka, M. and Katsumi, T.: Properties of separated soil generated through disaster waste treatment, Proceedings of 10th JGS Symposium on Environmental Geotechnics, JGS, pp. 355-360, 2013 (in Japanese).

19) Takai, A., Kawashima, M., Katsumi, T., Inui, T., Iwashita, S. and Okawara, M.: Quality and its variation of soils recovered from disaster debris in Iwate Prefecture after the 2011 East Japan earthquake, Journal of Japan Society of Civil Engineers, Ser. C (Geosphere Engineering), Vol. 72, No. 3, pp. 252-264, 2016. (in Japanese)

20) Katsumi, T., Takai, A., Inui, T., Okawara, M. and Kawashima, M.: Material properties of soils recovered from disaster debris in Iwate prefecture generated by the 2011
Great East Japan earthquake, Geo-Chicago 2016 - Sustainability, Energy, and the Geoenvironment, Geotechnical Special Publication No.269, D. Zekkos, A. Farid, A. De, K. R. Reddy and N. Yesiller (eds.), ASCE, pp. 274-283, 2016.

21) JGS Technical Committee on Recovered Geo-Materials: Use of Recovered Geo-Materials for the Disaster Recovery, https://www.jiban.or.jp/index.php?option=com_content\&v iew $=$ article\&id=1540\&Itemid=148, 2014 (in Japanese).

22) Katsumi, T.: Contribution of environmental geotechnics for disaster recovery, Proceedings of the Second Japan-India Workshop in Geotechnical Engineering, Japanese Geotechnical Society Special Publication, Vol. 3, No. 2, pp. 103-108, 2016.

23) JGS Technical Committee on Recovered Geo-Materials: Guideline of Utilization of Recovered Materials from Disaster Wastes, https://www.jiban.or.jp/index.php?option= com_content\&view $=$ article\&id $=1540 \&$ Itemid $=148,2014$ (in Japanese).

(Received November 9, 2016) 